\title{
Exacerbation of Facial Motoneuron Loss after Facial Nerve Transection in Severe Combined Immunodeficient (scid) Mice
}

\author{
Craig J. Serpe, ${ }^{1,3}$ Adam P. Kohm, ${ }^{1}$ Christopher B. Huppenbauer, ${ }^{1,3}$ Virginia M. Sanders,,$^{1,2}$ and \\ Kathryn J. Jones ${ }^{1,3}$
}

Departments of ${ }^{1} \mathrm{Ce} / \mathrm{B}$ Biology, Neurobiology, and Anatomy and ${ }^{2}$ Microbiology and Immunology, Loyola University Medical Center, Illinois 60153, '3epartment of Rehabilitation, Research and Development, Hines Veterans Administration Hospital, Hines, Illinois 60141

\begin{abstract}
The immune system functions to protect an organism against microbial infections and may be involved in the reparative response to nerve injury. The goal of this study was to determine whether the immune system plays a role in regulating motoneuron survival after a peripheral nerve injury. After a right facial nerve axotomy, facial motoneuron (FMN) survival in C.B-17 (+/+) wild-type mice was found to be $87 \pm 3.0 \%$ of the unaxotomized left side control. In contrast, facial nerve axotomy in C.B-17 (-/-) severe combined immunodeficient (scid) mice, lacking functional $\mathrm{T}$ and $\mathrm{B}$ lymphocytes, resulted in an
\end{abstract}

average FMN survival of $55 \pm 3.5 \%$ relative to the unaxotomized left side control. This represented an $\sim 40 \%$ decrease in FMN survival compared with wild-type controls. The reconstitution of scid mice with wild-type splenocytes containing $T$ and $B$ lymphocytes restored FMN survival in these mice to the level of the wild-type controls. These results suggest that immune cells associated with acquired immunity play a role in regulating motoneuron survival after a peripheral nerve injury.

Key words: scid; $T$ and $B$ Lymphocytes; neuroimmune interactions; FMN; acquired immunity; reconstitution
Over the last several years, an increasing amount of research has established that an interaction exists between the immune system and the nervous system (Besedovsky and del Rey, 1996). The search for evidence to support such an interaction has led to the discovery that the CNS is not as "immune privileged" as was once thought (Hickey et al., 1991; Knopf et al., 1995). Historically, the concept of the CNS as an immune privileged site stemmed from the characterization of a blood-brain barrier (BBB) made up of endothelial cells that restricted the passage of both large molecular weight soluble factors and cells into the CNS (Shrinkant and Benveniste, 1996). However, recent evidence has shown that activated $\mathrm{T}$ and $\mathrm{B}$ lymphocytes are able to cross the BBB (Hickey et al., 1991; Knopf et al., 1998) and that neuronal and glial cells residing in the CNS express receptors for cytokines secreted by these activated T cells (Rothwell et al., 1996).

Although it is well known that motoneurons in the adult peripheral nervous system generally survive and regenerate after a nerve injury (Lieberman, 1971), it is unclear which soluble factors and/or cell types mediate the ability of motoneurons to withstand injury. Recently, researchers have focused on the possibility that cells within the peripheral immune system may be involved in determining the survival and/or death of neurons after an injury. In adult mice, it has been well established that most facial motoneurons (FMNs) will survive facial nerve transection at the stylomastoid foramen (Torvik and Skorten, 1971; Sendtner et al., 1996; Ferri et al., 1997). If the peripheral immune

\footnotetext{
Received Feb. 10, 1998; revised March 24, 1999; accepted March 29, 1999.

This work was supported by National Institutes of Health Grants NS28238 (to K.J.J.) and AI37326 to V.M.S.). We thank Mary-Kay Olsen for expert assistance with the preparation of histological samples.

Drs. Jones and Sanders contributed equally to this work.

Correspondence should be addressed to: Craig J. Serpe, Department of Cell Biology, Neurobiology, and Anatomy, Loyola University Medical Center, 2160 South First Avenue, Maywood, IL 60153.

Copyright (C) 1999 Society for Neuroscience 0270-6474/99/190001-05\$05.00/0
}

system plays a role in motoneuron survival after a peripheral nerve injury, then mice lacking a functional peripheral immune system should show alterations in motoneuron survival after injury. Therefore, the present study was designed to test motoneuron survival in mice lacking cells associated with acquired immunity, specifically $\mathrm{T}$ and B lymphocytes.

Severe combined immunodeficient (scid) mice contain a spontaneously arising autosomal recessive mutation that is located on chromosome 16 (Bosma, 1989). These mutants lack a functional DNA repair mechanism essential for variable diversity-joining (VDJ) gene segment recombination, an immune mechanism that allows for the expression of a functional receptor for antigen on the T and B cell surface (Roth and Craig, 1998). Without this recombination event, mature $\mathrm{T}$ and $\mathrm{B}$ cells do not develop to populate lymphoid organs (Bosma and Carroll, 1991).

Given the plethora of data suggesting that the immune system influences the activity of the nervous system (Besedovsky and del Rey, 1996) and vice versa (Madden et al., 1995), we used the well established facial nerve axotomy and scid mouse models to determine whether $\mathrm{T}$ and $\mathrm{B}$ lymphocytes play a role in regulating FMN survival after injury to the facial nerve. Our results indicate that mice lacking $\mathrm{T}$ and $\mathrm{B}$ cells show reduced FMN survival by

This article is published in The Journal of Neuroscience, Rapid Communications Section, which publishes brief, peerreviewed papers online, not in print. Rapid Communications are posted online approximately one month earlier than they would appear if printed. They are listed in the Table of Contents of the next open issue of JNeurosci. Cite this article as: JNeurosci, 1999, 19:RC7 (1-5). The publication date is the date of posting online at www.jneurosci.org.

http://www.jneurosci.org/cgi/content/full/3105 
$\sim 40 \%$ compared with the wild-type controls and that reconstituting scid mice with splenocytes from wild-type mice restores FMN survival to that of wild-type controls.

\section{MATERIALS AND METHODS}

Animals. Seven-week-old female C.B-17 $(+/+)$ wild-type and C.B-17 $(-/-)$ scid mice were obtained from Taconic (Germantown, NY). All mice were provided autoclaved pellets and water ad libitum. Scid mice received tetracycline $\mathrm{HCl}(2 \mathrm{mg} / \mathrm{ml}$; Pfizer, New York, NY) in their drinking water $3 \mathrm{~d}$ /week. Mice were permitted 1 week to acclimate to their environment before being manipulated and used at 8 weeks of age in all experiments. Scid mice were housed under a $12 \mathrm{hr}$ light/dark cycle in microisolater cages contained within a laminar flow system to maintain a pathogen-free environment. All experimental manipulations were performed $\sim 4 \mathrm{hr}$ into the light cycle under aseptic conditions. All surgical procedures were completed in accordance with National Institutes of Health guidelines on the care and use of laboratory animals for research purposes.

Surgical procedures. Mice were anesthetized with $3 \%$ halothane for all surgical procedures. Using aseptic techniques, the right facial nerve of each animal was exposed at its exit from the stylomastoid foramen (Jones and LaVelle, 1985). The left facial nerve was exposed, but not transected, and served as a sham-operated internal control.

Cell-counting procedure. Four weeks after facial nerve transection, the brains were removed and rapidly frozen. Twenty-five micrometer cryostat sections were collected throughout the rostral-caudal extent of the facial motor nucleus. To determine the relative number of surviving facial motoneurons after a facial nerve axotomy, cell profile counts were performed. The sections were fixed in $4 \%$ paraformaldehyde and stained with thionin. The abducens nuclei and internal genu of the facial nerves were used to precisely match the location of the left (control) and right (transected) sides. Surviving FMNs containing a nucleus were counted, and the percentage change between the left and right sides was calculated and compared between groups. The Abercrombie correction factor $(N=$ $n \times T / T+D)$, where $N$ is the actual number of cells, $n$ is the number of nuclear profiles, $T$ is the section thickness $(25 \mu \mathrm{m})$, and $D$ is the average diameter of nuclei $(5 \mu \mathrm{m})$ (Coggeshall, 1992), was used to compensate for double counting in adjacent sections. Statistical analysis was accomplished using a one-way ANOVA.

Transfer of spleen cells into scid mice. Spleens were removed aseptically from C.B-17 $(+/+)$ wild-type mice and placed in HBSS and $5 \%$ fetal calf serum (FCS) (Summit Biotechnology, Ft. Collins, CO). The spleens were teased apart, and the splenic capsule was removed. Debris was allowed to settle from the suspension of cells for $5 \mathrm{~min}$ at room temperature before the cells were centrifuged at $280 \times g$ for $8 \mathrm{~min}$ at $4^{\circ} \mathrm{C}$. Red blood cells were lysed with ammonium chloride $(0.8 \%)$ for $4 \mathrm{~min}$ at $37^{\circ} \mathrm{C}$, and the remaining cells were washed in cRPMI [RPMI 1640 medium (Life Technologies, Grand Island, NY) containing 10\% FCS (Summit Biotechnology), $20 \mathrm{~mm}$ HEPES, $100 \mathrm{U} / \mathrm{ml}$ penicillin, $100 \mu \mathrm{g} / \mathrm{ml}$ streptomycin, $2 \mathrm{~mm}$ glutamate, and $50 \mu \mathrm{M}$ 2-mercaptoethanol]. The cell pellet was placed over Lympholyte M (Accurate, Westbury, NY) and centrifuged at $1510 \times g$ for $20 \mathrm{~min}$ at $4^{\circ} \mathrm{C}$. The interface of cells was collected using a cRPMI-coated pipette, and cells were washed twice in cRPMI and centrifuged at $280 \times g$ for $8 \mathrm{~min}$ at $4^{\circ} \mathrm{C}$. Splenocytes were resuspended in HBSS to $1 \times 10^{8}$ cells $/ \mathrm{ml}$, and $0.4 \mathrm{ml}$ was injected intravenously into the lateral tail vein of lightly anesthetized scid mice. Wildtype control mice were injected intravenously with $0.4 \mathrm{ml}$ of HBSS into the lateral tail vein.

Histology. Spleens were fixed in $10 \%$ formalin, embedded in paraffin, sectioned by microtome at $8 \mu \mathrm{m}$, and mounted on slides. Sections were rehydrated by a serial alcohol series and then stained with hematoxylin and eosin.

\section{RESULTS}

\section{Scid mice show decreased FMN survival}

A right facial nerve transection was performed on C.B-17 $(+/+)$ wild-type and C.B-17 (-/-) scid mice to determine whether mice compromised for acquired immunity, i.e., mice lacking functional $\mathrm{T}$ and $\mathrm{B}$ lymphocytes, would differ in FMN survival after a right facial nerve transection. C.B-17 $(+/+)$ wild-type mice after a facial nerve transection show FMN survival of $87 \pm 3.0 \%$, relative to that of the unaxotomized left side control (Figs. $1 A, B, 2 A$ ).
In contrast, scid mice had an FMN survival of $55 \pm 3.5 \%$, relative to the unaxotomized left side control. This represented an $\sim 40 \%$ decrease in survival in scid mice when compared with the wildtype controls (Figs. 1C,D, 2A).

\section{Transfer of mature $\mathrm{T}$ and $\mathrm{B}$ lymphocytes restores FMN survival}

If the immune system plays a role in regulating FMN survival, then restoring a functional immune system to scid mice should restore FMN survival after a right facial nerve axotomy. To test this proposal, we needed to establish a model system in which $\mathrm{T}$ and B lymphocytes restored immunocompetency to the scid mice. First, in comparison with a wild-type control (Fig. 2B), we showed that wild-type splenocytes injected into the scid mice migrated to, and segregated within, their respective compartments of the spleen and lymph node (LN) (Fig. 2D). No follicles or $\mathrm{T}$ and $\mathrm{B}$ lymphocytes were found within the spleen or $\mathrm{LN}$ of nonreconstituted scid mice (Fig. $2 C$ ). Reconstituted lymph nodes contained three defined areas including the medulla, the paracortex with $\mathrm{T}$ cells, and the cortex populated with B lymphocytes (data not shown). Because these mice appeared to reconstitute successfully, a facial nerve transection was performed in reconstituted scid mice to compare FMN survival with findings from wild-type controls and nonreconstituted scid mice. The transfer of splenocytes containing functional $\mathrm{T}$ and $\mathrm{B}$ lymphocytes into scid mice restored FMN survival to $86 \pm 3.0 \%$ of the unaxotomized left control after a right facial nerve transection (Figs. $1 E, F, 2 A$ ), a level of survival equivalent to that of wild-type controls. Thus, these results suggest that $\mathrm{T}$ and $\mathrm{B}$ cells play a role in regulating FMN survival after a facial nerve transection.

\section{DISCUSSION}

The CNS has long been considered an immune-privileged site (Shrinkant and Benveniste, 1996). However, the presence of cells and high molecular weight soluble factors within the CNS that are normally associated with the peripheral immune system, e.g., T lymphocytes and cytokines (Hickey et al., 1991; Rothwell et al., 1996), has led to the hypothesis that the peripheral immune system may play a role in regulating motoneuron survival after a peripheral nerve injury. This proposal was addressed in the present study by performing a right facial nerve transection on C.B-17 $(+/+)$ wild-type mice, C.B-17 (-/-) scid mice lacking functional $\mathrm{T}$ and $\mathrm{B}$ lymphocytes, and scid mice reconstituted with functional $\mathrm{T}$ and B lymphocytes. We observed a significant decrease in FMN survival in scid mice after a right facial nerve transection compared with wild-type controls. In contrast, reconstituting scid mice with immunocompetent $\mathrm{T}$ and $\mathrm{B}$ cells before a facial nerve transection restored FMN survival to the level of wild-type mice. These data suggest that $\mathrm{T}$ and/or B cells play a positive role in regulating FMN survival after an injury to the facial nerve.

The results of the present study suggest three possible hypotheses. First, T and B lymphocytes may directly affect FMN survival via an immune cell-nerve cell interaction. This interaction may result in FMN survival via a mechanism that involves an immune cell-derived contact- or soluble-mediated factor. Evidence that lends support for this hypothesis comes from recent data indicating that activated $\mathrm{T}$ and $\mathrm{B}$ cells cross the $\mathrm{BBB}$ and aggregate around FMNs after a facial nerve transection (Knopf et al., 1998; Raivich et al., 1998). In addition, another finding that lends support for this hypothesis is that neurons express receptors for cytokines secreted by activated T cells (Rothwell et al., 1996). 


\section{Low Power}

\section{control}
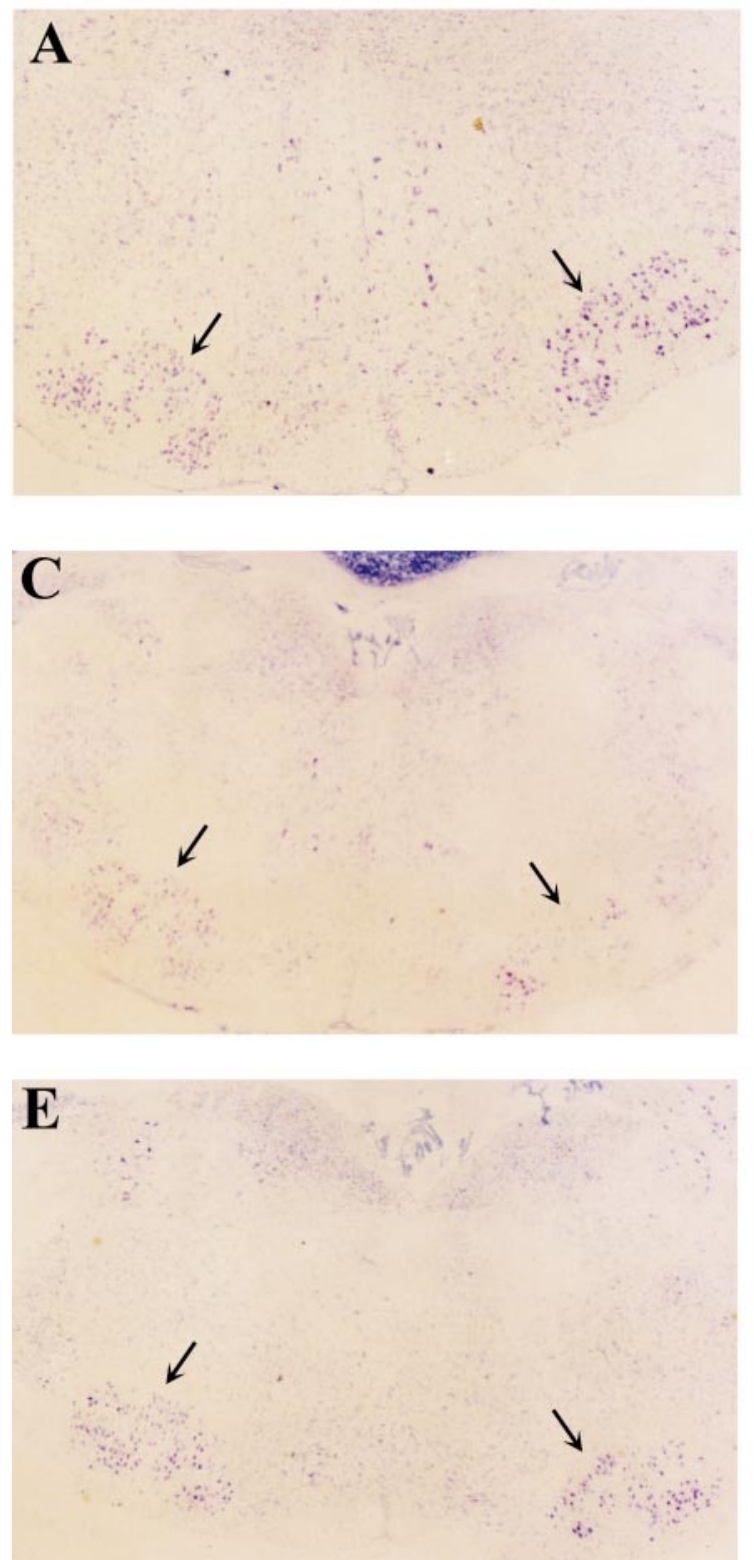

High Power
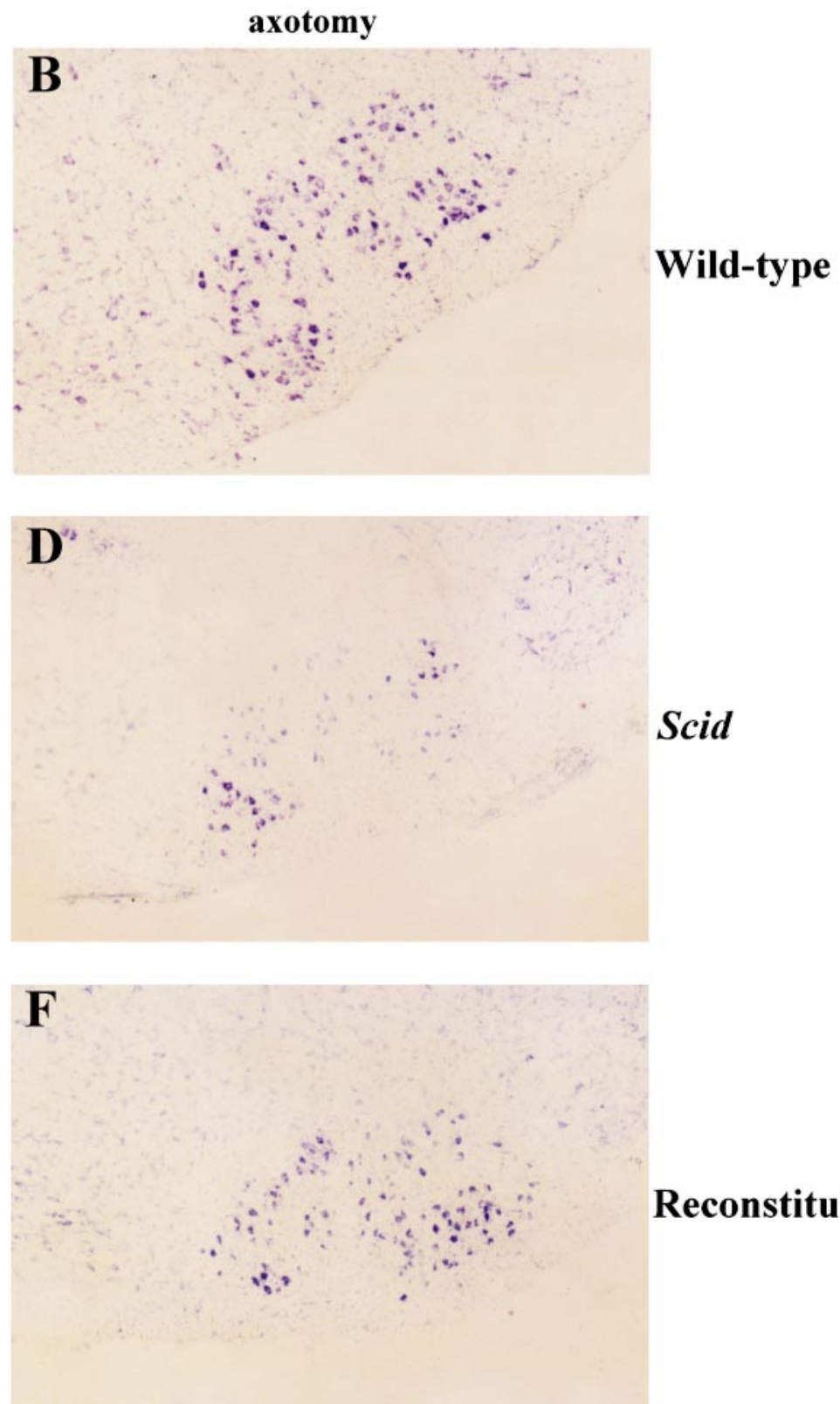

\section{Reconstituted}

Figure 1. Thionin-stained control and axotomized facial motor nuclei (arrows) 4 weeks after a facial nerve transection. $A$, C.B-17 $(+/+)($ wild-type) mouse (original magnification, $10 \times$ ). $B$, Enlargement of the axotomized facial motor nucleus from $A$ (original magnification, $20 \times$ ). $C$, C.B-17 ( $-/-$ ) (scid) mouse. $D$, Enlargement of the axotomized facial motor nucleus from $C$ (original magnification, $20 \times$ ). E. Reconstituted C.B-17 ( $-/-$ ) (scid) mouse. $F$, Enlargement of the axotomized facial motor nucleus from $E$ (original magnification, $20 \times$ ).

Thus, it has been shown that the machinery necessary for these interactions to occur is present within the facial motor nucleus, and their effects on FMN survival remain to be tested.

Second, soluble factors released from $\mathrm{T}$ and/or B cells may indirectly affect FMN survival by influencing the activity of other cells that reside constitutively in the scid mouse, such as microglia and macrophages. $\mathrm{T}$ cells may interact with microglia or macrophages to become activated to release cytokines that further activate bystander microglia or macrophages. Interferon- $\gamma$ (IFN$\gamma$ ), a cytokine released by activated T cells, is known to increase the activity of macrophages and microglia (Steeg et al., 1982;
Meda et al., 1995). Also, after a facial nerve transection, mRNAs for specific cytokines, i.e., mRNA for interleukin-1 $\beta$ (IL-1 $\beta$ ), tumor necrosis factor- $\alpha$, IL-6, and IFN- $\gamma$, are centrally upregulated in a yet to be determined cell type (Raivich et al., 1998; Streit et al., 1998). Alternatively, T cell-derived cytokines may act peripherally to affect FMN survival. Evidence to support this comes from recent data indicating that IL- $1 \beta$ can activate vagal afferents and mediate immune system to CNS communication (Goehler et al., 1997). Another possibility is that T and/or B cells may activate Schwann cells, which are a known source of nerve growth factor after peripheral nerve injury (Lindholm et al., 

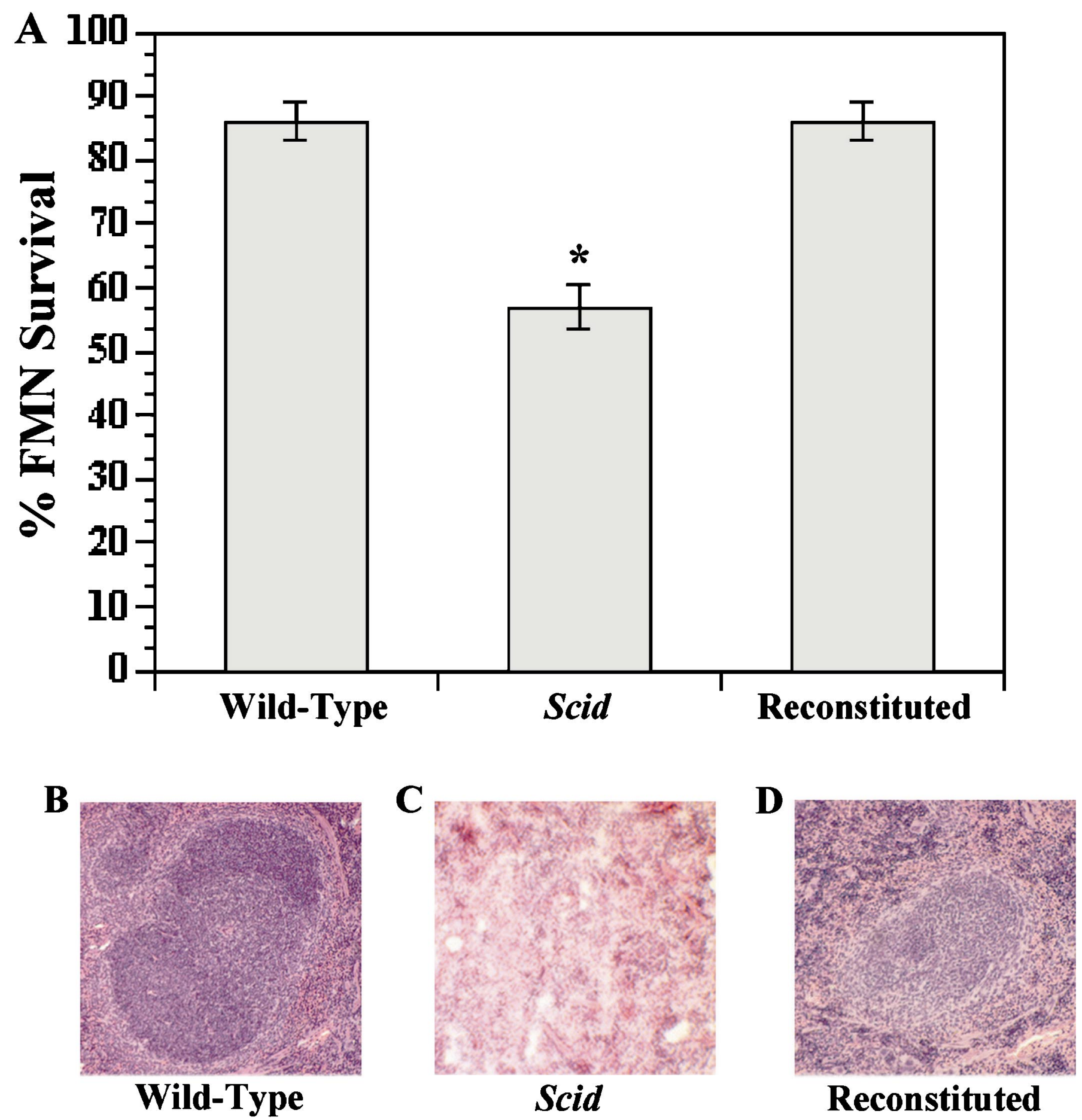

Reconstituted

Figure 2. A, Average percent survival \pm SEM of FMN from the right (transected) side of C.B-17 $(+/+)$ (wild-type, $n=7)$, nonreconstituted C.B-17 (scid, $n=7)$, and reconstituted C.B-17 $(-/-)($ scid, $n=6)$ mice, relative to the unoperated control side. * Significant difference at $p<0.5$. $B$, Follicle from a C.B-17 $(+/+)$ (wild-type) mouse containing a central artery, a periarterial lymphatic sheath, a marginal zone, and a marginal sinus. $C$, Representative spleen section from a C.B-17 (-/-) (scid) mouse containing no follicles. D, Follicle from a C.B-17 (-/-) (scid) mouse after reconstitution with splenocytes from wild-type mice.

1987). Collectively, these findings support the possibility that nerve injury-activated $\mathrm{T}$ and/or B cells may release cytokines that affect bystander cells playing a role in regulating FMN survival.

Third, the scid mutation is an autosomal recessive mutation that leads to the loss of a functional DNA repair mechanism in all cells (Fulop and Phillips, 1990). Therefore, although this mutation results in a loss of VDJ recombination mechanisms necessary for the production of mature $\mathrm{T}$ and $\mathrm{B}$ cells, it may also result in a loss of DNA repair mechanisms critical to FMN survival. This is unlikely, however, given our findings that FMN survival in reconstituted scid mice is restored to the level of wild-type mice. To confirm this finding, further experiments will be done using mice in which the recombinase-activating gene-2 (RAG-2) has been disrupted in T and B lymphocytes only (Shinkai et al., 1992). Use 
of RAG-2 knock-out mice will assure that the loss of gene function will affect only the production of mature $\mathrm{T}$ and $\mathrm{B}$ lymphocytes that populate lymphoid organs and will not affect motoneuron survival mechanisms that require DNA repair. In this manner, we will be able to rule out the scid mutation itself as a factor in FMN survival.

In summary, the data presented in the present study indicate that the immune system plays a critical role in neuronal survival after injury. Which immune cell types, soluble factors, and/or cell-cell interactions mediate the immune influences on the injured brain remain to be determined.

\section{REFERENCES}

Besedovsky HO, del Rey A (1996) Immune-neuro-endocrine interactions: facts and hypotheses. Endocr Rev 17:64-102.

Bosma GC (1989) The mouse mutation severe combined immunodeficiency (SCID) is on chromosome 16. Immunogenetics 29:54-57.

Bosma MJ, Carroll AM (1991) The SCID mouse mutant: definition, characterization, and potential uses. Annu Rev Immunol 9:323-350.

Coggeshall RE (1992) A consideration of neuronal counting methods. Trends Neurosci 15:9-12.

Ferri CC, Moore FA, Bisby MA (1997) Effects of facial nerve injury on mouse motoneurons lacking the p75 low-affinity neurtrophin receptor. J Neuobiol 34:1-9.

Fulop GM, Phillips RA (1990) The scid mutation in mice causes a general defect in DNA repair. Nature 347:479-482.

Goehler LE, Relton JK, Dripps D, Kiechle R, Tartaglia N, Maier SF, Watkins LR (1997) Vagal paraganglia bind biotinylated interleukin-1 receptor antagonist: a possible mechanism for immune-to-brain communication. Brain Res Bull 43:357-364.

Hickey WF, Hsu BL, Kimura H (1991) T-lymphocyte entry into the central nervous system. J Neurosci Res 28:254-260.

Jones KJ, LaVelle A (1985) Changes in nuclear envelope invaginations in axotomized immature and mature hamster facial motoneurons. Brain Res 353:241-249.

Knopf PM, Cserr HF, Nolan SC, Wu TY, Harling-Berg CJ (1995) Physiology and immunology of lymphatic drainage of interstitial and cerebrospinal fluid from the brain. Neuropathol Appl Neurobiol 21:175-180.

Knopf PM, Harling-Berg CJ, Cserr HF, Basu D, Sirulnick EJ, Nolan SC, Park JT, Keir G, Thompson EJ, Hickey WF (1998) Antigendependent intrathecal antibody synthesis in the normal rat brain: tissue entry and local retention of antigen-specific B cells. J Immunol 161:692-701.

Lieberman AR (1971) The axon reaction: a review of the principle features of perikaryal responses to axon injury. Int Rev Neurobiol $14: 49-125$.

Lindholm D, Heumann R, Meyer M, Thoenen H (1987) Interleukin-1 regulates synthesis of nerve growth factor in non-neuronal cells of rat sciatic nerve. Nature 330:658-659.

Madden KS, Sanders VM, Felten DL (1995) Catecholamine influences and the sympathetic neural modulation of immune responsiveness. Annu Rev Pharmacol Toxicol 35:17-48.

Meda L, Cassatella MA, Szendrel GI, Otvos Jr L, Baron P, Villalba M, Ferrari D, Rossi F (1995) Activation of microglial cells by $\beta$-amyloid protein and interferon- $\gamma$. Nature 374:647-650.

Raivich G, Jones LL, Kloss CUA, Werner A, Neumann H, Kreutzberg GW (1998) Immune surveillance in the injured nervous system: T-lymphocytes invade the axotomized mouse facial motor nucleus and aggregate around sites of neuronal degeneration. J Neurosci 18:5804-5816.

Roth RB, Craig NL (1998) VDJ recombination: a transposase goes to work. Cell 94:411-414.

Rothwell NJ, Luheshi G, Toulmond S (1996) Cytokines and their receptors in the central nervous system: physiology, pharmacology, and pathology. Pharmacol Ther 69:85-95.

Sendtner M, Gotz R, Holtmann B, Escary JL, Masu Y, Carroll P, Wolf E, Brem G, Bruket P, Thoenen H (1996) Cryptic physiological trophic support of motoneurons by LIF revealed by double gene targeting of CNTF and LIF. Curr Biol 6:686-694.

Shinkai Y, Rathbun G, Lam K, Oltz EM, Stewart V, Mendelsohn M, Charron J, Datta M, Young F, Stall AM, Alt FW (1992) RAG-2 deficient mice lack mature lymphocytes owing to inability to initiate $\mathrm{V}(\mathrm{D}) \mathrm{J}$ rearrangement. Cell 68:855-867.

Shrinkant P, Benveniste EN (1996) The central nervous system as an immunocompetent organ. J Immunol 157:1819-1822.

Steeg PS, Moore RN, Johnson HM, Oppenheim JJ (1982) Regulation of murine macrophage Ia antigen expression by a lymphokine with immune interferon activity. J Exp Med 156:1780-1793.

Streit WJ, Semple-Rowland SL, Hurley SD, Miller RC, Popovich PG, Stokes BT (1998) Cytokine mRNA profiles in contused spinal cord and axotomized facial nucleus suggest a beneficial role for inflammation and gliosis. Exp Neurol 152:74-87.

Torvik A, Skjorten F (1971) Electron microscopic observations on nerve cell regeneration and degeneration after axon lesion. II. Changes in the glial cell. Acta Neuropathol (Berl) 70:491-499. 